\title{
Exploring Effects of Science-Technology-Society Instructional Approach as an Innovation in Improving Learners' Interest in Chemistry
}

\author{
Benson Ikechukwu Igboanugo \\ Science Education Department, \\ Alex Ekwueme Federal University, Ndufu-Alike \\ Abakaliki, Ebonyi State, Nigeria \\ Email: benson.igboanugo [AT] funai.edu.ng
}

\begin{abstract}
Continuous dwindling in learners' interest in chemistry is a threat to global development. The abstract nature of chemistry and other factors are capable of damping the interest of the learner during instruction which can mar the realization aims and objectives of chemistry instruction. The learning environment is shaped by the instructional approaches adopted by the teacher. Thus, the use of innovative instructional approach capable of making the learning experiences relevant to the learner, build and sustain the interest in the learner during chemistry instruction becomes very imperative. This study investigated Science-technology-society (STS) instructional approach as an innovation in improving learners' interest in chemistry. The study was conducted using senior secondary school 2 chemistry learners in Onitsha Education zone of Anambra state, South-East of Nigeria. The study adopted quasi experimental design of the pretest posttest non equivalent control group design. Two research questions and two hypotheses guided the study. Three hundred and ten students from purposively sampled twelve coeducational public secondary schools were used for the study. Six schools were randomly assigned to the treatment group while the remaining six assigned to the control group. The treatment group was taught electrolysis using Science-technologysociety instructional approach while the control group was taught the electrolysis using the conventional instructional approach. Validated Chemistry Interest Inventory (CII) was used to collect data for the study. The CII had reliability index of 0.93. The mean score and standard deviation were used to answer the research questions while analysis of variance (ANCOVA) was used to test the hypotheses at 0.05 level of confidence. The study revealed among other things that there was significant difference in the interest mean scores of learners taught chemistry using Science-technologysociety instructional approach and those taught chemistry using conventional instructional approach. From the findings of the study, the following recommendations among others were made: Chemistry teachers should adopt STS instructional approach in teaching and learning chemistry and use of STS instructional approach should included in chemistry teacher education programme.
\end{abstract}

Keywords---- Science-technology-society, Instructional Approach, Innovation, Interest and Chemistry

\section{INTRODUCTION}

Chemistry deals with the utilization of natural substances and the creation of artificial ones, for the utmost benefit of the society. The utility values of the nations' raw materials can be harnessed through chemistry (Achimugu, 2016). Through application of chemistry knowledge, quality of life is enhanced by creation of goods and services; wealth and jobs. Also through chemistry knowledge, such ills as environmental pollution and food poisoning which are fallouts from chemical interactions are controlled (Ikokwu and Eke, 2017). The importance of chemistry for nation building cannot be over emphasized. Considering the indisputable importance of chemistry in nation building and development, Nigerian government has rightly included chemistry in the Senior Secondary School (SSS) curriculum as a core science subject (FME, 2007). In attempt to ensure realization of the envisaged national development through chemistry education, the Nigerian government introduced a new curriculum in 2007 that will suit the ever changing socio-cultural conditions of Nigeria.

However, the realization of the chemistry aims/objectives according to Okorie (2018) is confronted by hydraheaded problems which include inadequate distribution of qualified chemistry teachers to schools, inadequate provision of equipments and instructional resources to schools, use of ineffective mode of instructions by chemistry teachers, and students' poor attitude and lack of interest. Researchers such as Widinda (2017) and Uzochi, Nweke, \& Fatokun (2017) report a general continuous dwindling in learners' interest in chemistry at the secondary school level across the globe which has negative effects on national/global developments. 
Interest, an aspect of affective domain is a construct that has to do with ones readiness to like or dislike something. It could be aroused in an individual by activity that tends to satisfy the individual's needs (Achufusi, Nwadike \& Adimonyema, 2017). The person-object theory of interest points to the fact that interest of the learner can be developed out of relationships between the learner and the learning experience. One of the objectives of Chemistry curriculum is 'to develop interest in the subject of Chemistry (FME, 2007). This stresses the need to build learners' interest in learning Chemistry. Interest is an intrinsic force that is capable of propelling an individual towards realization of the aims and objectives of a given human endavour. Learners' interest in Chemistry instruction is a measure of the learners' readiness to willfully undertake learning activities in Chemistry. Learner's interest in Chemistry is of two stages. The first stage is the interest to choose chemistry as a necessary subject of study. The second stage is the consummating interest which spans through topics/assignments during the course of study. Some factors that can influence the interest of the learner in chemistry are teaching resources/equipment, mode of instruction, teacher quality, peer group influence, parents priority (Anaekwe \& Unachukwu, 2013).

The availability of teaching resources and equipment for chemistry instruction can concretize chemistry concepts, create a novelty scenario, and vary stimuli which build the learner's interest. The views/opinions of the peer group about the nature and benefits of the chemistry can mar or promote the learner's interest. Furthermore, parent's priority can determine from the onset whether the learner will have interest to choose chemistry as a subject of study required for a particular profession. The interest of the learner is nurtured and sustained if handled by a qualified teacher who knows his/her onions in teaching and learning chemistry (Widinda, 2017).

The myriads of challenges in teaching and learning chemistry such as abstract nature of the topics/concepts, and the voluminous contents/activities call for serious efforts in capturing, nurturing and maintaining students' interest in chemistry. Researchers such as Ogbonne \& Offorma (2013) and Akram, Ijaz \& Ikram (2017) contend that interest is an important variable in realizing chemistry aims and objectives. Danjuma \& Nwagbo (2013-2017) observe that learners' interest is significantly correlated with the instructional approaches used by the teacher. In this regard, Okeke \& Ikokwu (2017) maintain that the observed students' lack of interest in Chemistry can be averted through the Chemistry teacher's use of innovative instructional approaches.

Instructional approaches are systematic procedures employed by teachers in attempt to help learning take place. Instructional approaches shape the learning environment. As part of the lesson design, a particular instructional approach or set of instructional approaches capable of building the learner's interest are selected by an effective chemistry teacher to engage learners in learning (Akani, 2013). For a chemistry lesson to be interesting to the learner and objectives realized, Wagbara (2013-2017) opine that learners should be actively involved in the lesson. But in contrary, the conventional instructional approach often used by most chemistry teachers reduces learners to mere passive listeners with little or no interest (Fatokun, Egya \& Uzoechi, 2016). Learners perceive chemistry concepts and topics to be difficult and abstract mainly due to the ineffective conventional instructional approach adopted by most chemistry teachers (Aniodoh \& Eze, 2014). In addition, according to Onyegegbu (2018), conventional instructional approaches tend to be competitive and gender discriminatory against the females.

Gender is a social construct that assigns behaviour to male and female separately. Busola (2011) adduce to the fact that girls lose interest in science at primary school level more than boys. Akram, Ijaz \& Ikram (2017) opined that gender and teacher factors can affect the learner's interest in chemistry. Such teacher factors include teacher's qualifications, and the teacher's modes of instruction. Consequently, an innovation in mode of instruction capable of building and holding learner's interest in learning science irrespective of gender is essential.

Innovation has to do with introduction of new things, ideas or ways of doing something. Innovation in instruction searches for effective new dispositions in teaching and learning that aid in improving the outcomes of teaching and learning enterprises rather than continuous dependent on the outrageous, boring and ineffective conventional ways and methods of instruction.

Considering the abstract and difficult nature of most chemistry concepts and topics, a host of researchers such as Njoku (2015), Uzoechi, Nweke \& Fatokun (2016) and Attah \& Njoku (2018) suggest adoption of innovative, studentcentred modes of instruction in chemistry. The innovative instructional approaches are the ideas/strategies of efficaciously accomplishing the goals of teaching chemistry (Akani, 2013). The innovative instructional approaches do not only ignite and hold the interest of the learners, but permeate the abstract concepts and topics for easy understanding and realization of chemistry aims and objectives ( Danjuma \& Nwagbo, 2013-2017). Although the effects of many innovative instructional approaches such as cooperative learning, peer tutoring, use of learning organizer on teaching and learning of chemistry have been explored but the observed poor performance and lack of interest by senior secondary school chemistry learners persist (Ojokoku, 201; WAEC, 2015 and WAEC, 2016). Thus, Attah \&Njoku (2018) calls for further investigation into such innovative modes of instruction that relates chemistry instruction to learner's socio-cultural background such as Science-technology-society instructional approach. 
Science-Technology-Society (STS) instructional approach is an innovative mode of instruction that is based on the constructivists' ideology. It focuses on teaching and learning from the learner's perspective of the issue at hand. Using Science-Technology-Society instructional approach in chemistry instruction considers the learner's perspective of the reallife problems and processes which have chemistry and technology components. According to Mansour (2007) ScienceTechnology-Society (STS) instructional approach makes traditional concepts and processes found in typical science and social studies programmes more appropriate and relevant to the students.

Science-Technology-Society (STS) instructional approach relates chemistry instruction to the life experiences of the student which makes the learning experience meaningful and relevant to the learner (Njoku, 2009). For instance, in teaching electrolysis, instead of beginning with the concepts in electrolysis, and writing the chemical equations for the reactions, the teacher begins with the utility values of electrolysis such as, what are the effects of electricity on matters? Can electricity bring about chemical reactions? Can chemical reactions generate electricity? Helping students to provide answers to such problems relates the underlying chemistry concepts or principles to students' day to day experiences. This will boost students' interest in chemistry. From the fore going, the worthwhile questions might be: Is STS instructional approach capable of improving learners' interest in chemistry? Does STS instructional approach as an innovation in instruction have gender bias in improving learners' interest in chemistry? Those questions constitute the problem of this study.

\section{PURPOSE OF THE STUDY}

The purpose of this study is to determine the effects of STS instructional approach on learners' interest in Chemistry. In specific terms the study set out to determine the effects of STS instructional approach on:

i) Learners' interest in chemistry

ii) Interest of male and female learners in chemistry

\section{SCOPE OF THE STUDY}

This study was carried out in Onitsha Education zone of Anambra state, South-East of Nigeria. Learners' achievement in chemistry in this area has been observed by the researcher to be poor. The content area used is electrolysis which is one of the content areas perceived difficult by learners (WAEC, 2015 and 2016).

The study was guided by the following research question:

\section{RESEARCH QUESTIONS}

i) What are the interests mean scores of learners taught chemistry using STS instructional approach?

ii) What are the interests mean scores of male and female learners taught chemistry using STS instructional approach?

\section{HYPOTHESES}

The following null hypotheses were formulated and tested at an alpha level of 0.05 :

$\mathrm{HO}_{1}$ : There is no significant difference between the interests mean scores of learners taught chemistry using STS instructional approach and those taught using conventional approach.

$\mathrm{HO}_{2}$ : There is no significant difference between the interests mean scores of male and female learners taught chemistry using STS instructional approach.

\section{METHODOLOGY}

The quasi experimental design was adopted for this study. Specifically the pretest post-test nonequivalent control group design was used for the study. The design is represented thus:

$\mathrm{O}_{\mathrm{b}} \mathrm{XO}_{\mathrm{a}}$

$-\underline{O}_{b} \simeq X \underline{O}_{a}{ }_{2}$

$\mathrm{X}=$ Treatment (STS instructional approach)

$\sim \mathrm{X}=$ Control (Conventional instructional approach)

$\mathrm{O}_{\mathrm{b}}=$ Pretest measurement

$\mathrm{O}_{\mathrm{a}}=$ Post-test measurement

Indication that treatment and control groups are not got by random assignment of subjects to conditions. 


\section{Population of the Study}

The population of the study comprised of all the Senior Secondary School 2 (SSS2) Chemistry learners in Onitsha Education zone of Anambra state, Nigeria.

A sample of 310 SSS2 chemistry learners from purposively sampled twelve coeducational secondary schools was used in the study. Treatment and control groups were assigned to the schools at random. Six schools were assigned to the treatment group and the remaining six schools assigned to the control group.

\section{Instrument for Data Collection}

Chemistry Interest Inventory (CII) constructed by the researcher was used to collect data for the study. The CII was made up of 30 items that covered student's interest in chemistry. It was a four-point scale. Each item has the options of, strongly agree, agree, disagree and strongly disagree. The scale for the options was; strongly agree, 4 points; agree, 3 points; disagree, 2 points and strongly disagree, 1 point for positive statements while the reverse was the case for negative statements. The instrument was face validated by two experts in chemistry education, one expert in measurement and evaluation and one secondary school chemistry teacher to ensure that each of the items was understandable and relevant to SS2 students who constituted the sample for the study. The CII was trial tested on 33 SS2 students of a secondary school outside the zone of study. The trial test helped to improve the quality of the test items, estimate the time it might take for an average student to effectively complete the test and confirm the face validity of the items. Furthermore, from the result of the trial test, reliability of the instrument was determined using Cronbach's Alpha Reliability Coefficient. This gave an internal consistency estimate of 0.93 .

\section{Experimental Procedure}

Two instructional approaches were used for the study. Science-technology-society instructional approach was used in teaching the treatment group while the conventional instructional approach was used in teaching the control group. The regular chemistry teachers on permission from the school authorities were trained and used as research assistants, who helped to carry out the teaching in their respective schools. This arrangement has advantage of removing the hawthorn effect which might occur when a strange teacher teaches the students. The teachers were trained for three weeks to conform strictly to the STS instructional approach lesson plan as prepared by the researcher. In the control group, the regular teachers taught in their respective schools using the usual conventional instructional approach. The same topics in electrolysis were taught in both the treatment group and the control group. A pretest was administered to the subjects using the validated CAT, marked and recorded by the researcher before the experiment commenced. The experiment was carried out during normal school hours using the school time table for the classes. The experiment lasted for five weeks. On the last day of the experiment, a post-test was administered to the subjects using the validated CII, marked and recorded by the researcher. The CII used in the post-test was the same in content with the CII used in the pretest but differed in the sequence of items. The data collected from the pretest and post-test were used to answer the research questions and test the hypotheses for the study.

The research questions were answered using mean and standard deviation of the interest scores. The hypotheses were tested using Analysis of Covariance (ANCOVA).

\section{RESULTS}

The results of the study are presented in tables 1,2 and 3 .

\section{Research Question1:}

What are the interest mean scores of learners taught chemistry using STS instructional approach?

Table 1: Mean scores and standard deviations of learners' interest in chemistry

\begin{tabular}{|lcccccc|}
\hline Groups & Pretest & & Post-test & Gain mean & Number of \\
& & & & & \\
& Mean & Std Dev & Mean & Std Dev & score & \\
& & & & & & \\
\hline Experimental (STS) & 55.90 & 9.21 & 86.66 & 21.19 & 30.76 & 157 \\
& & & & & & 153 \\
Control (Conventional method) & 72.99 & 13.33 & 71.66 & 14.81 & -1.33 & \\
\hline
\end{tabular}


From Table1 it can be observed that the interest mean score for the STS group in the post-test is 86.66 and the interest mean score of the conventional method in the in the post-test is 71.66. The group taught using STS instructional approach with gain mean score of 30.76 seems to be favoured than the group taught with conventional approach with gain mean score of -133 . Whether the difference in the mean interest scores of the two groups is significant or not was ascertained by testing hypothesis 1 at $\mathrm{p}<0.05$.

\section{Research Question 2:}

What are the interest mean scores of male and female learners taught chemistry using STS instructional approach?

Table 2: Mean scores and standard deviations of male and female learners' interest in chemistry due to interactive effects of gender and STS instructional approach

\begin{tabular}{|c|c|c|c|c|c|c|c|}
\hline \multirow[t]{2}{*}{ Groups } & \multirow[t]{2}{*}{ Gender } & \multicolumn{2}{|c|}{ Pretest } & \multicolumn{2}{|c|}{ Post-test } & Gain mean & \multirow{2}{*}{$\begin{array}{r}\text { Number of } \\
\text { subjects }\end{array}$} \\
\hline & & Mean & Std Dev & Mean & Std Dev & score & \\
\hline \multirow[t]{2}{*}{ Experimental (STS) } & Male & 54.73 & 9.11 & 85.44 & 11.63 & 30.71 & 85 \\
\hline & Female & 57.07 & 9.31 & 87.88 & 9.56 & 30.81 & 72 \\
\hline \multirow[t]{2}{*}{ Control (Expository) } & Male & 74.03 & 13.95 & 72.53 & 14.81 & -1.50 & 90 \\
\hline & Female & 71.94 & 12.71 & 70.79 & 12.20 & -1.15 & 63 \\
\hline
\end{tabular}

Summary of Table 2 reveals that the difference in the interest mean scores of male and female scores exposed to STS instructional approach is meager. Whether the meager difference in the mean interest scores of the male and female scores is significant or not was ascertained by testing hypothesis 2 at $\mathrm{p}<0.05$.

\section{Hypotheses}

$\mathrm{HO}_{1}$ : There is no significant difference between the interests mean scores of learners taught chemistry using STS instructional approach and those taught using conventional approach.

Table 3: Summary of Analysis of covariance (ANCOVA STS instructional approach on learners' interest in chemistry

\begin{tabular}{lllllll}
\hline Source & $\begin{array}{l}\text { Type III } \\
\text { Squares }\end{array}$ & Sum & of & & & \\
Co & & Mean Square & F & Sig. \\
\hline Corrected Model & $17187.783^{\mathrm{a}}$ & 1 & 4296.946 & 28.135 & .000 \\
Intercept & 60995.175 & 1 & 60995.175 & 399.382 & .000 \\
Pretest Interest & 14.686 & 1 & 14.686 & .096 & .757 \\
Method & 10556.620 & 1 & 10556.620 & 69.122 & .000 \\
Gender & 9.433 & 1 & 9.433 & .062 & .804 \\
Method * Gender & 342.236 & 1 & 342.236 & 2.241 & .135 \\
Error & 46580.800 & 305 & 152.724 & & \\
Total & 2012249.000 & 310 & & & \\
Corrected Total & 63768.584 & 309 & & & \\
\hline
\end{tabular}

The result in Table 3 shows that the probability value of 0.000 associated with teaching methods is less than 0.05 level of significance. Thus, the null hypothesis of no significant difference between the interest mean scores of students taught chemistry using STS instructional approach and those taught using conventional approach is rejected. The researcher therefore, concludes that the difference between the interest mean scores of learners taught chemistry using STS instructional approach and those taught using conventional approach is significant.

$\mathrm{HO}_{2}$ : There is no significant difference between the interests mean scores of male and female learners taught chemistry using STS instructional approach.

The result in Table 3 shows that the probability value of 0.804 associated with gender is greater than 0.05 level of significance. Thus, the null hypothesis of no significant difference between the interest mean scores of male and female learners taught chemistry using STS instructional approach is upheld. 


\section{DISCUSSION}

The result of this study has shown that STS instructional approach is effective innovation in enhancing learners' interest in chemistry. Results from Table 3 show that there is significant difference between the interests mean scores of learners taught chemistry using STS instructional approach and those taught using conventional approach $(\mathrm{F}(1,305)=$ 69.122, $\mathrm{P}=0.000$ ). This finding is in consonance with Njoku (2009) who maintains that STS instructional approach enhances implementation of the senior secondary school chemistry curriculum by building learners' interest.

The implication is that through proper integration of chemistry as science with its applications in technology and social issues and values, STS instructional approach makes chemistry concepts and phenomena more tangible, reduces the abstract nature of the concepts and phenomena therefore learning chemistry becomes more meaningful to the learner. This is consonance with Okeke and Ikokwu (2017) who maintain that meaningful learning captures and retains students' interest in chemistry. Science-technology-society instructional approach starts with the students' problems instead of the chemistry concept thus learners' interest and problems are addressed at the onset of an instruction which should be a gateway to enhancement of students' outcomes in chemistry.

Learners' active participation in the teaching-learning process which is a necessary condition for effective learning to take place is assured through the use of STS instructional approach. This is in congruent with Danjuma \& Nwagbo (20132017) who posit that learner-based instructional approach is efficacious in improving students' interest in Science. Again since STS instructional approach is learner-centred and more activity oriented, it is more efficacious than the conventional instructional approach. Learners' lack of interest and the resultant poor outcomes in chemistry instruction could be addressed if the chemistry teacher adopts an innovative instructional approach such as STS instructional approach which presents chemistry concepts /topics from the learners' perspectives.

Again, results in Table 3 Show that there is no significant difference between the interests mean scores of male and female learners taught chemistry using STS instructional approach $(\mathrm{F}(1,305)=0.062, \mathrm{P}=0.804)$. This is in consonant with Danjuma \& Nwagbo (2013-2017) who maintain that there is no significant difference between male and female students interest mean scores taught science using learner based instructional approach. STS instructional approach carries every learner along during the instruction from the individual learner's perspective of the topic/concept thereby building and sustaining interest on the individual learner irrespective of the sex. This confirms STS instructional approach a unisex instructional approach with respect to learners' interest in chemistry instruction.

\section{RECOMMENDATIONS}

From the findings of this study, the following recommendations are made as possible solutions to improving learners' interest in chemistry instruction for better learning outcome.

1) Chemistry teachers should adopt the STS instructional approach in teaching and learning chemistry.

2) Chemistry teachers should encourage, and pay equal attention to the interest of both male and female learners by adopting the STS instructional approach in teaching and learning chemistry.

3) STS instructional approach should be emphasized and incorporated into the chemistry teacher education curriculum in tertiary institutions of learning. This is to make the instructional approach popular among in-training teachers who would apply it in teaching chemistry.

4) Professional organizations such as Science Teachers Association of Nigeria (STAN) and ministry of education should popularize the effective use of STS instructional approach in teaching and learning chemistry among the in-serving chemistry teachers through seminars, workshops, conferences and publications.

\section{CONCLUSION}

Lack of interest in learning chemistry found among learners is caused by such factors as the nature of chemistry and the instructional approach adopted by the teacher. This mars realization of expected learning outcomes in chemistry and bedevils national development. It has become obvious from this study that STS instructional approach is an innovation that addresses the problem of learners' lack of interest and the resultant poor outcomes in chemistry. Chemistry teachers should embrace the use of STS instructional approach in teaching and learning chemistry in senior secondary schools. This study therefore, calls for intervention of stakeholders in education to help publicize the use of STS instructional approach in teaching and learning chemistry in order to boost learner's interest and ensure improvement in instructional outcomes for individual and national development. Some of the suggestions made in this study could be of help.

\section{REFERENCES}

Achimugu, L. (2016). Investigation into the extent of use of field tripinstructional strategy in the implementation senior secondary school Chemistry curriculum in Kogi State, Nigeria. Journal of ScienceTeachers Association of Nigeria 51(1), 142-151. 
Achufusi, J.N.; Nwadike, C.C. \& Adimonyema, R.N. (2017). Utilization of local resources by Biology teachers: effects on students learning, attitudes and sustainable development. Journal of Science Education, School of Science Nwafor Orizu College of Education Nsugbe, Anambra State 13 (1),317-322..

Akani, O. (2013). Innovation in STEM curricula: A Strategy for the Attainment of the Millennium Development goals in Nigeria. 54th annual conference Proceedings of Science Teachers Association of Nigeria, 1624.

Akpoghol, T.V.; Ezeudu, F.O.; Adzape, J.N \& Otor, E.E (2016). Effects of lecture method supplemented with music and computer animation on senior secondary school students' academic achievement in electrochemistry. Journal of Education and Practice 7(4), 75-86. www.iiste.org.

Akram, T.M., Ijaz, A \& Ikram, H. (2017). Exploring the factors responsible for declining students' interest in Chemistry. International Journal of Information and Education Technology, Vol. 7, No. 2, February 201788doi: 10.18178/ijiet.2017.7.2.847

Aniodoh, H. C.O. and Eze, G. N. (2014). Achieving effectiveness in secondary school chemistry classrooms using constructivist approach: a case study of physical and chemical changes. 55th Annual Conference Proceedings of Science Teachers Association of Nigeria, 247-252.

Attah, F. O. \& Njoku,Z.C. (2018). Effects of two teaching methods on secondary school students achievement in writing and balancing chemical equations. In Z.C. Njoku, U.M.Nzewi \&

C.V. Nnaka (eds). Perspectives on Science and Technology Education in Nigeria (pp. 302-310). Nsukka-Nigeria: Great AP Express Publishers.

Busola, A.J (2011). Gender difference in students' achievement in Chemistry in secondary schools of Kakamega District, Kenya. Retrieved from www.scholarsresearchlibrary.com on 16-06 2011.

Danjuma, G,S \& Nwagbo, C (2013-2017). Effects of collaborative and competitive learning strategies on junior secondary II students interest in Basic Science. Journal of the Department of Science Education University of Nigeria Nsukka 3(1), 58-65

Egolum, E.O. and Igboegwu, E.N. (2013). Meeting the challenges of MDGs through Chemistry curriculum reforms and implementation in secondary schools: A strategy for the attainment of the Millennium Development Goals (MDGs). 54th Annual Conference Proceedings of Science Teachers Association of Nigeria, 10-15.

Fatokun, K.V.F., Egya, S.O \& Uzoechi, B.C. (2016). Effect of games instructional approach on chemistry students' achievement and retention in periodicity. European Journal of Research and Reflection in Educational Sciences 4(7), 29-39.

Federal Ministry of Education (2007). Senior secondary education curriculum Chemistry for SS1-3. Abuja. Nigerian Education Research and Development Council.

Idah, N.N: Egbo, J.J \& Okechineke, B.C (2016). 57th Annual Conference Proceedings of Science Teachers Association of Nigeria, 433-450

Ikokwu, P.I.I. and Eke, J.A. (2017). Chemistry education for sustainable environmental pollution management in Onitsha metropolis. Journal of Science Education, School of Science Nwafor Orizu College of Education Nsugbe, Anambra State 13 (1),297-301.

Mansour, N. (2007). Challenges to STS education: Implication for Science Teacher Education. Bulletin of Science, Technology and Society, $\quad$ 6, (27), 482-497.

Njoku, Z.C. (2015). Resolving students' learning difficulties in secondary School Chemistry. Paper presented at the ISTE International Conference on Mathematics, Science and Technology Education. Mopani Camp, Kruga National Park, Limpopo, South Africa Oct. 25-30, 2015.

Nnoli, J.N. (2016). Assessment of available Chemistry material resources and secondary school students' level of acquisition of entrepreneurial skills. Journal of Science Teachers Association of Nigeria 51(1),127-134.

Nwafor, C. E. and Umuoke, J. (2014). Science, Technology and Mathematics education for creativity: challenges and prospects. 55th Annual Conference Proceedings of science Teachers Association of Nigeria, 141-145. 
Ogbonne, U.T. and Oforma, G. C. (2013). Effect of collaborative learning method on secondary students' interest in English. International Journal of Educational Research, 12(2), 12-135.

Ojokuku, G.O. (2015). Keynote address towards effective teaching of metals and their compounds in senior secondary school Chemistry. STAN Chemistry panel series 11. A Hand Book for Chemistry Teachers, 4-7.

Okeke, S.O.C and Ikokwu, P.I.I. (2017). The effect of concept mapping and simulation playmethods on students' interest in Organic Chemistry. Journal of Science Education, School of Science Nwafor Orizu College of Education Nsugbe, Anambra State 13 (1), 290-296.

Okorie E.U. (2018). Introduction to Special Methods in Chemistry.Lagos: Springfield Book, 37- 44

Onyegegbu, N. (2018). Enhancing Nigerian school girls' potentials in STEM: Breaking barriers into STEM careers. In Z.C. Njoku, U.M.Nzewi \& C.V. Nnaka (eds). Perspectives on Science and Technology Education in Nigeria (pp.140-149). Nsukka-Nigeria: Great AP Express Publishers.

Ugwuada, A.O. and Odo, J.A. (2014). Re-engineering, science, technology, engineering and mathematics (STEM) education for creativity development in Nigeria. 55th Annual Conference Proceedings of Science Teachers Association of Nigeria, 55-60.

Unachukwu, G.O and Anakwe, M.C (2013). Parental collaboration and secondary school students' achievement in Chemistry. International Journal of Educational Research, 12(2), 289-295.

Uzochi, B.C.; Nweke, P.I. \& Fatokun, K.V.F. (2017). Effects of ethno-science teaching approach on students' achievement and interest in separation techniques. Journal of Science Teachers Association of Nigeria 52(1)13-18.

Wagbara, O.S (2013-3017). Influence of cognitive styles and school location on secondary school students' interest in Chemistry. Journal of the Department of Science Education University of Nigeria Nsukka 3(1), 168-175

West African Examination Council (2015). Chief examiners report. Lagos: Federal Ministry of Education.

West African Examination Council (2016). Chief examiners report. Lagos: Federal Ministry of Education.

Widinda, N.A. (2017). An analysis of interest in students' learning of Physical Chemistry experiment using scientific approach. International Journal of Science and Applied Science Conference Series 2 (2), 109-116. Doi:10.20961/ijsascs.v1:2.5130. 